UDC 616.61-008.64

DOI: $10.21668 /$ health.risk/2020.2.18.eng

\title{
CHRONIC KIDNEY DISEASE: PREVALENCE AND RISK FACTORS (LITERATURE REVIEW)
}

\author{
A.M. Aringazina ${ }^{1}$, O.Zh. Narmanova ${ }^{2}$, G.O. Nuskabaeva ${ }^{3}$, Zh.A. Tagaeva ${ }^{3}$, E.S. Mendybaev ${ }^{4}$ \\ ${ }^{1}$ Kazakhstan's medical university «Kazakhstan School of Public Health», 19 A Utepov Str., Almaty, 050060, \\ The Republic of Kazakhstan \\ ${ }^{2}$ Astana medical university, 49A Beibitshilik Str., Nur-Sultan, 010000, The Republic of Kazakhstan \\ ${ }^{3}$ Akhmet Yassawi International Kazakh-Turkish University, 29 B Sattarkhanova Ave., Turkestan, 161200, \\ The Republic of Kazakhstan \\ ${ }^{4}$ Kazakh medical university of continuing education, 34 Manasa Str., Almaty, 050057, The Republic of Kazakhstan
}

Chronic kidney disease (CKD) is a complex of syndromes that occurs as an outcome of various kidney diseases or as a complication caused by diseases of other organs; it often exerts maximum influence on prognosis for a primary disease. It seems an urgent task to improve early CKD diagnostics and reveal risk factors that can cause unfavorable clinical course and development of the pathology. Finding solution to this task will allow reducing terms and improving organization of specialized medical aid provided for patients. The issue related to detection of health risk factors is especially pressing in countries with low and middle incomes. National and international efforts aimed at preventing, detecting, and treating chronic kidney diseases are necessary for decreasing worldwide mortality and morbidity.

The article presents a review of literature data accumulated in PubMed, Elsevier, and Google Scholar databases on epidemiologic issues concerning chronic kidney diseases. We managed to find more than 150 materials; more than 40 articles out of them were analyzed and they turned out to dwell on different aspects of the issue. Special attention is paid to CKD prevalence among population depending on a country, ethnic group, age, and sex as well as to examining risk factors occurring in a specific region or a country.

Literature analysis allowed concluding that CKD prevalence has grown substantially over the last 10 years. Among risk factors there are medical parameters (prevalence of chronic cardiovascular diseases and endocrine system diseases) and social and demographic conditions. It is shown that CKD tends to occur more frequently among people from black race than those from other races. But black people have higher survivability after dialysis than their white counterparts from the same age groups. Awareness about CKD risk factors among population and doctors providing primary medical assistance predetermines efficiency of early diagnostic and further treatment of the disease in low income countries.

Key words: chronic kidney disease, glomerular filtration rate, terminal kidney failure, prevalence, risk factors, epidemiology.

Non-communicable diseases are among leading death causes all over the world. Chronic kidney disease (CKD) is among those pathologies that cause mortality including untimely deaths. Over the last decade
CKD prevalence has been growing steadily simultaneously with a rapid growth in number of people suffering from cardiovascular diseases and pancreatic diabetes. In 2016 CKD resulted in 1.19 million death cases all over

(C) Aringazina A.M., Narmanova O.Zh., Nuskabaeva G.O., Tagaeva Zh.A., Mendybaev E.S., 2020

Altyn M. Aringazina - Doctor of Medical Sciences, Head of the Department for Public Health and Social Sciences (e-mail: altyn.aringazina@gmail.com; tel.: +7 (777) 277-46-07; ORCID: https://orcid.org/0000-0002-9056-2394).

Oryngul' Zh. Narmanova - Doctor of Medical Sciences, Professor at the Department for Public Health and Social Sciences (e-mail: oryngul.winner@gmail.com; tel.: +7 (701) 575-55-95; ORCID: https://orcid.org/0000-0002-4957-1475).

Gul'naz O. Nuskabaeva - Candidate of Medical Sciences, acting as Associate Professor, Head of the Department for Specialized Clinical Courses (e-mail: g_nuskabaeva@mail.ru; tel.: +7 (705) 285-31-31; ORCID: https://orcid.org/0000-0003-2139-3221).

Zhanat A. Tagaeva - doctoral candidate (e-mail: zhanet16-16@mail.ru; tel.: +7 (702) 336-00-75; ORCID: https://orcid.org/0000-0001-7087-8474).

Ermek S. Mendybaev - doctoral candidate (e-mail: mendybayev@gmail.com; тел.: +7 (702) 544-81-59; ORCID: https://orcid.org/0000-0002-7616-8497). 
the world that was by $28.8 \%$ higher than in 2006. It allowed CKD to take the $11^{\text {th }}$ rank place among death causes in 2016 against the $13^{\text {th }}$ and $27^{\text {th }}$ rank place in 2013 and 1990 accordingly. The WHO predicts that in 2030 CKD will hold the $13^{\text {th }}$ rank place among death cases [1].

Apart from effects produced on mortality growth, CKD also exerts significant influence on population life quality and economic results achieved in a country or a region. Hence, fighting against global CKD epidemic is a vital and complicated task that requires, among other things, early detection of people with arterial hypertension, pancreatic diabetes, and other risk factors. In this case screening as a procedure aimed at detecting potential patients with CKD is important and economically efficient [2]. Experts revealed differentiated inverse dependence between cardiovascular risks and glomerular filtration rate (GFR) that was not dependent from age, sex, and other risk factors [3]. Kidney functional reduction is a predictor of hospitalization, cognitive dysfunction, and low life quality [4-8]. Low awareness about CKD in many countries can crate obstacles for early intervention and some researchers recommend raising this awareness about the disease among people [2].

CKD doesn't only result in deaths but also leads to a significant decrease in life quality and disability. Cross-questioning performed in the USA allowed revealing that difficulties in everyday life were much more frequently mentioned by patients with CKD than by those who didn't suffer from it [9]. Besides, CKD frequently aggravates other chronic diseases such as pancreatic diabetes, hypertension, and cardiovascular diseases and it can impose additional limitations on people's functional abilities. The latest WHO report on global diseases burdens stated that over the last 10 years overall number of lost healthy years due to CKD grew significantly from 29.2 thousand to 35.0 thousand. This calculated amount is higher than one calculated for many neurological disorders including dementia, Parkinson disease and chronic renal failure as well [10].
Remarkably, CKD is also related to substantial expenses on medical services. In the state register in Sweden annual expenses on medical aid rendered to patients suffering from CKD (without dialysis) were 4 times higher than those rendered to an average patient; in case hemodialysis was applied, the difference grew to 45 times [11].

According to KDOQI (Kidney Disease Outcomes Quality Initiative), CKD can be classified into five stages [12] using CKD parameters and data on structural changes in the kidneys (for example, proteinuria). Other recommendation as per NICE allows dividing the stage 3 into $3 \mathrm{a}$ and $3 \mathrm{~b}$ that reflect a growth in cardiovascular risks [13]. As per data obtained via a retrospective study performed in Great Britain, the highest CKD stage is stage 3 determined in more than $90 \%$ cases. $84 \%$ out of them are stage 3 a (glomerular filtration rate (GFR) varies from 45 to $59 \mathrm{ml} / \mathrm{min} / 1 \cdot 73 \mathrm{~m}^{2}$ ) and $16 \%$ are stage $3 \mathrm{~b}$ (GFR is from 30 to $44 \mathrm{ml} / \mathrm{min} / 1 \cdot 73 \mathrm{~m}^{2}$ ) [14].

CKD reasons vary depending on a country, ethnic group, and age.

Changes in CKD prevalence over time are rather controversial. Data obtained via the Third National Health and Nutrition Examination Survey revealed that over a period from 1999 to 2004 CKD stage 1-4 prevalence grew considerably in comparison with a period from 1988 to $1994 \quad(13.1 \%$ against $10.0 \%$ ) [15-17]. Although this high prevalence is partially due to population becoming older, it is also related to growth in hypertension and pancreatic diabetes prevalence [3]. However, results obtained via representative crossstudies performed in Great Britain allowed revealing that prevalence decreased over time within national borders [18].

Diabetic nephropathy is the most widely spread kidney disease that results in renal replacement therapy (RRT) in the USA (44\%) and Great Britain $(27.5 \%)[19,20]$. On the contrary, primary glomerulonephritis is a basic reason for kidney failure or end-stage renal disease (ESRD) in China [21]. However, approximately 10-15\% patients who had ESRD didn't have any specific renal diagnosis $[19,22]$. 
N.R. Hill et al., researchers at Oxford Universality, performed a systematic review and meta-analysis on the subject; they revealed that average CKD prevalence was higher from stage 1 to $5(13.4 \%$ against $11.0 \%)$. CKD cases distribution as per stages performed with the use of all the available data was as follows: stage 1 (GFR> 90) $3.5 \%(2.8-4.2 \%)$; stage 2 (GFR 60-89) $3.9 \%(2,7-5.3 \%$ ); stage 3 (GFR 30-59) 7.6\% (6.4-8.9\%); stage 4 (GFR 29-15) $0.4 \% \quad(0.3-0.5 \%)$, and stage $5 \quad(\mathrm{GFR}<15)$ $0.1 \%(0-0.1 \%)$. It was impossible to analyze specific data on stages $3 a / 3 b$ due to absence of reports on them. Besides, the same research revealed that a growth in person's age made a significant contribution into CKD prevalence. A growth in CKD frequency with age can be due to peculiarities of applied formulas where an age is usually inversely proportionate to CKD value [3].

K.T. Mills et al. performed a systematic review on CKD prevalence in the world over a period from 2006 to 2013. The results are given in Table 1 [23].

Table 1

Research performed by K.T. Mills; CKD stages depending on sex, age and country income, $\%$

\begin{tabular}{|c|l|c|c|}
\hline № & \multicolumn{1}{|c|}{ CKD stages } & Men & Women \\
\hline 1 & $\begin{array}{l}\text { CKD stages 1-5 } \\
\text { among adults } \\
\text { aged } \geq 20\end{array}$ & $\begin{array}{c}10.4 \\
(9.3-11.9)\end{array}$ & $\begin{array}{c}11.8 \\
(11.2-12.6)\end{array}$ \\
\hline 1.1 & $\begin{array}{l}\text { High income } \\
\text { countries }\end{array}$ & $\begin{array}{c}8.6 \\
(7.3-9.8)\end{array}$ & $\begin{array}{c}9.6 \\
(7.7-11.1)\end{array}$ \\
\hline 1.2 & $\begin{array}{l}\text { Low and middle } \\
\text { income countries }\end{array}$ & $\begin{array}{c}10.6 \\
(9.4-13.1)\end{array}$ & $\begin{array}{c}12.5 \\
(11.8-14.0)\end{array}$ \\
\hline \multirow{2}{*}{2} & $\begin{array}{l}\text { CKD stages 3-5 } \\
\text { among adults } \\
\text { aged } \geq 20\end{array}$ & $\begin{array}{c}4.7 \\
(3.4-6.7)\end{array}$ & $\begin{array}{c}5.8 \\
(4.4-8.1)\end{array}$ \\
\hline 2.1 & $\begin{array}{l}\text { High income } \\
\text { countries }\end{array}$ & $\begin{array}{c}4.3 \\
(3.5-5.2)\end{array}$ & $\begin{array}{c}5.7 \\
(4.4-7.6)\end{array}$ \\
\hline 2.2 & $\begin{array}{l}\text { Low and middle } \\
\text { income countries }\end{array}$ & $\begin{array}{c}4.6 \\
(3.1-7.7)\end{array}$ & $\begin{array}{c}5.6 \\
(3.9-9.2)\end{array}$ \\
\hline
\end{tabular}

When performing their meta-analysis, the authors noted that 51 works out of 100 examined one contained data on CKD prevalence varying depending on sex. Average
CKD prevalence among men (95\% confidence interval for research in which 5 CKD stages were determined) amounted to $12.8 \%$ $(10.8-11.9 \%)$, and the parameter amounted to $8.1 \%(6.3-10.2 \%)$ for research in which stages 3-5 were determined. CKD prevalence among women at stage 1-5 amounted to $14.6 \%(12.7-16.7 \%)$, and to $12.1 \%$ for research in which stages 3-5 were determined. N.R. Hill, S.T. Fatoba, and J.L. Oke noted that CKD was more widely spread among women than among men [3].

B. Bowe, Y. Xie, T. Li, and A.H. Mokdad examined morbidity with CKD stage 3-5 detected when patients were rendered primary medical-sanitary aid; over the examined period (2010-2014) it amounted to 71.9 per 1,000 people with huge difference as per geography (urban/rural settlements), sociodemographic factors (age, deprivation), and clinical factors (number and type of concomitant diseases).

Overall CKD prevalence was inversely proportionate to its gravity (3a stage, 31.8 per 1,000; 3b stage, 25.3 per 1,000; stage $4,11.7$ per 1,000; and stage 5, 3.3 per 1,000 thousand). There were no substantial differences in prevalence as per patients' sex.

Graver CKD stages were widely spread among elderly people ( $\geq 65$ years old), especially among people aged from 75 to 80 (345.1 per 1,000) and people older than 80 (397.6 per 1,000).

There was great CKD prevalence among people with 3 or more concomitant diseases; overall, it was equal to 281.7 per 1,000 people, most of them having stages $3 \mathrm{a}$ and $3 \mathrm{~b}$ (98.9 and 109.6 per 1,000 people). CKD prevalence was high among people with comorbid dementia $(303.3$ per 1,000$)$, pancreatic diabetes and arterial hypertension combined (267.4 per 1,000 people), Parkinson disease (223.7 per 1,000 people), and chronic obstructive lung disease (221.3 per 1,000 people) [24].

In Kazakhstan comorbidity was examined by O.J. Narmanova in 2008. The author revealed high prevalence of factors making for CKD growing progressively worse in patients with glomerular diseases: 23.37 exam- 
ined patients had arterial hypertension; $31.73 \%$, diagnostically significant proteinuria; $56.03 \%$ suffered from anemia; $35.49 \%$ patients had hypoproteinemia. A direct correlation was detected between prevalence of the revealed factors and CKD and an inverse one between CKD and comorbidity. Analysis of CKD prevalence among dispensary patients suffering from $\mathrm{AH}$, pancreatic diabetes, and primary and secondary nephropathy revealed that $71.5 \%$ examined patients had CKD stages $1-2 ; 17.7 \%$, stage $3 ; 1.3 \%$ stages $4-5$ that is, functional disorders in the kidneys were irreversible ${ }^{1}$.

As regards geography, higher CKD prevalence was detected in rural areas (86.2 per 1,000 people) than in urban ones (68.4 per 1,000 people). Literature contains a lot of data on factors that determine inequality regarding health preservation in remote urban and rural settlements; the most widely spread ones are remoteness from public healthcare organizations, geographical isolation, limited number of medical aid suppliers, and socioeconomic factors [24].

When analyzing chronic diseases burden in the USA, researchers revealed that over a period from 2002 to $2016 \mathrm{CKD}$ burden was growing in the USA and was ahead of other non-communicable diseases. Over the last 15 years in the USA certain changes have occurred in demographic, social, and epidemiologic trends. Those changes probably made for changes in chronic kidney disease (CKD) epidemiology.

In the USA an increase in CKD DALY was related to an increase in susceptibility to risk (40.3\%), ageing (32.3\%), and population growth $(27.4 \%)$. CKD parameters standardized as per age increased by $18.6 \%$ with a growth in metabolic risk factors and, to a lesser extent, in diet-related ones that amounted to $93.8 \%$ and $5.3 \%$ accordingly [24].

CKD in the South Asia has the same widely variable prevalence as in developed countries. Reasons that cause CKD are differ- ent, and in some regions there is high prevalence of CKD caused by glomerulnephritis and obstructive nephropathy as well as CKD with unknown etiology [25].

When analyzing these collaborators in studies on global diseases burden in the USA over a period from 2002 to 2016, researchers revealed a $52.6 \%$ growth in CKD DALY. CKD burden grew in all the states but rates of change (2002-2016) and burden in 2016 varied depending on a particular state. States on the south (including Mississippi and Louisiana) had burden that was more than 2 times higher than in other states (for example, CKD DALY standardized as per age amounted to 321 per 1,000 in Vermont whereas in Mississippi it amounted to 697 per 1,000 people).

Similar heterogeneity was detected in European countries. For example, prevalence of CKD stages from 1 to 5 varied from $3.31 \%$ in Norway to $17.3 \%$ in the northwest Germany; prevalence of CKD stages from 3 to 5 varied from $1.0 \%$ in the central Italy to $5.9 \%$ in the northwest Germany. Similarly, in Asian countries, for example, in China, prevalence of CKD stages from 1 to 5 varied greatly, from $6.7 \%$ in the southern China to $18.3 \%$ in the southwest China [25].

O.Yu. Gerasimova and L.N. Semchenko noted in their works that in Russia there were no available authentic data on a number of patients who suffered from kidney diseases and chronic renal failure. From 2003 to 2013 a number of urogenital system diseases grew by $31.6 \%$. In 2013 a number of patients suffering from renal failure on average amounted to 44.6 per 100 thousand people and it was 2.2 times higher than in 2003 [26].

B.T. Bikbov and N.A. Tomilina noted in the first part of the report issued basing on data provided by the Russian register of substitute kidney therapy that annual growth in number of people suffering from CKD was well in line with world trends [27]. O.I Apolikhin et al. stated that a number of patients with CKD on average grew by $9.9 \%$ every year [28].

\footnotetext{
${ }^{1}$ O.J. Narmanova. Epidemiologic and medical-organizational aspects of improving specialized medical aid rendered to patients with chronic renal failure: abstract of the thesis ... Doctor of Medical Sciences. Astana, 2008, 140 p. (in Russian).
} 
CKD prevalence as per geographical regions was also examined by British researchers. The results revealed that CKD prevalence was higher in developed regions such as Europe, USA, Canada, and Australia, than in regions with developing economies such as African countries located south from Sahara and India, excluding Iran where similar parameters were high. Research results are given in Table 2 [3]. CKD prevalence is probably predetermined with nutritional disorders, high body mass index (BMI), high systolic blood pressure, and concomitant diseases that are spread in a specific country [19].

Table 2

CKD prevalence as per geographic regions

\begin{tabular}{|c|c|c|}
\hline Regions & $\begin{array}{c}\text { CKD stages } \\
1-5 \% \\
(95 \% \mathrm{CI})\end{array}$ & $\begin{array}{c}\text { CKD stages } \\
3-5 \% \\
(95 \% \mathrm{CI})\end{array}$ \\
\hline $\begin{array}{l}\text { South Africa, Sene- } \\
\text { gal, Congo }\end{array}$ & $\begin{array}{c}8.66 \\
(1.31-16.01)\end{array}$ & $\begin{array}{c}7.60 \\
(6.10-9.10)\end{array}$ \\
\hline India, Bangladesh & $\begin{array}{c}13.10 \\
(11.01-15.19) \\
\end{array}$ & $\begin{array}{c}6.76 \\
(3.68-9.85) \\
\end{array}$ \\
\hline Iran & $\begin{array}{c}17.95 \\
(7.37-28.53) \\
\end{array}$ & $\begin{array}{c}11.68 \\
(4.51-18.84) \\
\end{array}$ \\
\hline $\begin{array}{l}\text { China, Taiwan, } \\
\text { Mongolia }\end{array}$ & $\begin{array}{c}13.18 \\
(12.07-14.30) \\
\end{array}$ & $\begin{array}{c}10.06 \\
(6.63-13.49) \\
\end{array}$ \\
\hline $\begin{array}{l}\text { Japan, South Korea, } \\
\text { Oceania }\end{array}$ & $\begin{array}{c}13.74 \\
(10.75-16.72)\end{array}$ & $\begin{array}{c}11.73 \\
(5.36-18.10) \\
\end{array}$ \\
\hline Australia & $\begin{array}{c}14.71 \\
(11.71-17.71) \\
\end{array}$ & $\begin{array}{c}8.14 \\
(4.48-11.79) \\
\end{array}$ \\
\hline The USA, Canada & $\begin{array}{c}15.45 \\
(11.71-19.20)\end{array}$ & $\begin{array}{c}14.44 \\
(8.52-20.36)\end{array}$ \\
\hline Europe & $\begin{array}{c}18.38 \\
(11.57-25.20)\end{array}$ & $\begin{array}{c}11.86 \\
(9.93-13.79) \\
\end{array}$ \\
\hline
\end{tabular}

K.T. Mills et al. reported in their research work that overall CKD prevalence depending on stage 1 to 5 varied from 4.5 to $25.7 \%$ in South Korea; from $4.1 \%$ among men in Salvador and Saudi Arabia to $16.0 \%$ among women in Singapore; CKD stage from 3 to 5 varied from $1.3 \%$ among men in China to $15.4 \%$ among men in Nepal, and from $1.7 \%$ among women In Singapore to $21.3 \%$ among women in Nepal [23]. $12.5 \%$ adults aged 40 and older suffered from CKD in Pakistan [29].
CKD prevalence depending on an ethnic group was examined by Pakistan researchers. In Pakistan CKD prevalence was estimated as per different communities in several research works. T.H. Jafar et al. (2003) estimated proteinuria prevalence as a CKD marker in four ethnic groups. They detected the highest prevalence among Sindhi $(9.5 \%$ among men and $10.3 \%$ among women) and Muhajir (8.2\% among men and $4.7 \%$ among women); the lowest prevalence was detected among Baluchi $(2.4 \%$ among men and $4.2 \%$ among women) and Pashtun (2.5\% among men and $1.2 \%$ among women) [25].

Arabs account for approximately $20 \%$ of population in Israel. In the country socioeconomic position and other difference regarding Arabs can create a situation similar to that of African Americans in the USA [30]. According to the Register on Kidneys maintained by «Israeli Society of Nephrology and Hypertension» and «Israel Center for Disease Control» by the end of 2007 there were 4,800 patients with CKD in Israel including $23 \%$ ethnic Arabs (both Muslim and Arabian Christians). From 1997 to 2007 in Israel the disease frequency grew by $71 \%$ [30].

Approximately $11 \%$ adults in the USA probably have a chronic kidney disease that is progressing into its irreversible form and at present can't be cured. B.B. Newsome et al. reported in several research works that 125 thousand African Americans, being 6.5\% of the overall examined sampling (1.9 million people), accounted for $14.9 \%$ cases of progressing CKD [31].

«Healthy People 2020», a program existing in the USA, has been focusing on the nation health over the last few years. Its goal is to assess and predict changes in public healthcare. Among other things, assessment includes analyzing specific risk factors that cause CKD and end-stage renal disease (ESRD) [32]. As we can see from Table 3, it was revealed within «Healthy People 2020» implementation that CKD prevalence grew both among African Americans and their white counterparts [33, 34]. 
Table 3

Patients treated due to CKD as per race/ethnic group, data provided by «Healthy People 2020»

\begin{tabular}{|l|c|c|c|c|c|}
\hline \multirow{2}{*}{ Parameters } & \multicolumn{2}{|c|}{ Black/ African Americans } & \multicolumn{2}{|c|}{ White } & $\begin{array}{c}\text { Targets approved } \\
\text { within «Healthy } \\
\text { People 2020» }\end{array}$ \\
\cline { 2 - 6 } & 2006 & 2015 & 2006 & 2015 & $30.4 \%$ \\
\hline $\begin{array}{l}\text { \% of patients with CKD c treated } \\
\text { by a nephrologist at least 12 } \\
\text { months prior to substitute kidney } \\
\text { therapy start }\end{array}$ & $23.2 \%$ & $32 \%$ & $27.9 \%$ & $37 \%$ & 312.1 \\
\hline $\begin{array}{l}\text { New ESRD cases per 1 million } \\
\text { people }\end{array}$ & 1114 & 895 & 294 & 352 \\
\hline $\begin{array}{l}\text { \% of patients who had kidney } \\
\text { transplantation within 3 years time } \\
\text { since ESRD was diagnosed }\end{array}$ & $9.1 \%$ & $7 \%$ & $21 \%$ & $16.2 \%$ & $20.1 \%$ \\
\hline $\begin{array}{l}\text { Number of deaths per 1,000 pa- } \\
\text { tient-years for people on dialysis }\end{array}$ & 170.9 & 135.8 & 258.1 & 207.4 & 187.4 \\
\hline
\end{tabular}

When estimating patients' health within Composite Health Care System (CHCS) procedures, experts obtained the following results: overall, 8,318 patients were examined, 5,849 $(70.3 \%)$ of them were whites, $1,344(16.2 \%)$ were blacks, and 1,125 (13.5\%) belonged to other races that were not identified. CKD stage 3 was diagnosed in 5,459 white patients (93.3\%), and stage 4, in 390 (6.7\%). CKD stage 3 was diagnosed in 1,205 black patients $(89.7 \%)$, and stage 4 , in $139(10.3 \%)$. People belonging to unidentified races had CKD stage 3 in $94.7 \%$ cases (1,065 patients), and stage 4 in $5.3 \%$ cases (60 patients) [35].

There was a study on determining ethnic differences in chronic kidney disease progressing among people suffering from pancreatic diabetes in Great Britain performed with the use of data taken from East London database over a period from 2006 to 2016; the study revealed that 6,274 patients out of 120,591 adults with pancreatic diabetes also had CKD; those patients aged 25-84 were whites, South Asian people, and blacks. $81.5 \%$ white people had CKD stage 3a; $15.7 \%$, stage $3 \mathrm{~b}$; and $2.8 \%$, stage $4.82 .9 \%$ South Asian people had CKD stage 3a; $13.9 \%$, stage $3 \mathrm{~b}$; and $3.2 \%$, stage $4.83 .6 \%$ black patients had CKD stage $3 \mathrm{a} ; 13.2 \%$, stage $3 \mathrm{~b}$; and $3.2 \%$ stage 4 [36].
Approximately $25 \%$ people with CKD have very poor literacy regarding health and it to a greater extent influences people with low socioeconomic position and obviously results in greater risks of adverse clinical outcomes $[37,38]$.

Raising awareness and literacy among population is a basic task in fighting CKD; it is also very important to early detect the disease and provide a patient with treatment by a nephrologist already at its early stages [2]. The latter is especially significant due to CKD developing mostly symptomless at early stages (before major renal failure occurs) [39].

Absence of awareness about CKD all over the world can be partially due to CKD diagnostics being based on laboratory blood tests (creatinine contents in blood serum or cystatin $\mathrm{C}$ contents necessary for estimating glomerular filtration rate (GFR)) and urine tests (for urine sediments, especially albuminuria); these tests are probably less available than a tonometer or a glucometer that are used in hypertension and diabetes diagnostics. A wide-scale examination performed in Canada revealed alarmingly low awareness about CKD as only $8 \%$ patients suffering from it knew their diagnosis; elderly people and women less frequently knew 
about it [40]. Overall awareness about CKD among population in general and even population groups running high cardiovascular risks amounted to less than $10 \%$ in 12 countries with low and middle incomes [41]. Research performed in Hong Kong revealed that less than a half of its citizens knew that hypertension and diabetes, being the major ESRD causes, could damage kidney functions [42].

T.H. Jafar et al. performed a quantitative study and revealed that not only patients were poorly aware about $\mathrm{CKD}$; doctors working in primary healthcare were also rather ignorant. Doctors who took part in the study mentioned limited knowledge and lack of confidence in a possibility to cure CKD at its early stage. Though doctors working in primary healthcare knew such terms as «urea» and «creatinine», they didn't perform preventive CKD screening among their patients and didn't treat those who suffered from it; instead, they sent such patients to specialized medical organizations. Also some doctors noted that cultural beliefs and standards of their patients often contradicted clinical recommendations and it created additional problems in treating CKD [43-45].

Doctors from two towns in Cameroon took part in a study focusing on determining literacy among medical personnel; the study revealed that only $58.8 \%$ questioned doctors were able to determine CKD correctly. Less than a half (44\%) knew that CKD had 5 stages and $73.8 \%$ wrong answers were given by specialists in the field. It was also revealed that more than $90 \%$ doctors knew basic risk factors that caused CKD; more than $80 \%$ knew basis CKD complications; and more than $90 \%$ knew that hemodialysis and transplantation were basic tools used in substitute kidney therapy. But still, peritoneal dialysis that was not used in the country at that moment was poorly known to questioned doctors. As regards detecting CKD, some doctors $(12.7 \%)$ still relied solely on creatinine in blood serum when diagnosing the disease. Accordingly, patients in Camer- oon were not aware about CKD and its complications and doctors weren't able to properly slow down the disease progressing up to ESRD in such patients [44].

Therefore, our examination of literature sources on chronic kidney disease prevalence has yielded the following results:

- chronic kidney disease occurs in approximately $12 \%$ of the overall world population. CKD prevalence is growing steadily together with other most significant noncommunicable diseases;

- CKD risk factors are pancreatic diabetes, arterial hypertension, cardiovascular diseases, high body mass index, as well as socialdemographic factors such as population growing older, low incomes, medical aid being poorly available, and low awareness about CKD among patients and doctors working in primary health care;

- most studies on CKD prevalence concluded that the disease was more frequent among women than among men. Average CKD prevalence among men (95\% confidence interval for studies where $5 \mathrm{CKD}$ stages were determined) amounted to $12.8 \%$ (10.8-11.9\%) and to $8.1 \%(6.3-10.2 \%)$ for studies where CKD stages 3-5 were determined. CKD prevalence among women for studied where stages 1-5 were determined amounted to $14.6 \%(12.7-16.7 \%)$ and to $12.1 \%$ for studied where stages $3-5$ were determined;

- studies perform over a period from 2006 to 2013 revealed that CKD prevalence in countries with middle and low incomes was higher than in countries with high incomes. However, British researchers revealed in their works performed prior to 2014 that CKD prevalence was higher in developed regions such as Europe, the USA, Canada, and Australia that in regions with developing economies such as African countries located south from Sahara and India;

- Composite Health Care System (CHCS) database contained data on a number of new ESRD cases being 2.8 times higher among blacks than among whites in the USA; number 
of deaths per 1,000 patient-years among people on dialysis was 1.5 times lower among blacks. It indicates that CKD is more frequent among black people but they survive dialysis more often than their white counterparts of the same age;

- regardless of all above mentioned determinants, raising awareness and literacy among doctors working in primary healthcare is the major task in fighting $\mathrm{CKD}$; early detection and timely treatment promotes less frequent transitions of the disease from its 3 and 4 stages into stage 5 , a terminal one.

Funding. The research was not granted any sponsor support.

Conflict of interests. The authors declare there is no any conflict of interests.

\section{References}

1. GBD 2016 Causes of Death Collaborators. Global, regional, and national age-sex specific mortality for 264 causes of death, 1980-2016: A systematic analysis for the Global Burden of Disease Study 2016. Lancet, 2017, vol. 390, no. 10100, pp. 1151-1210. DOI: 10.1016/S01406736(17)32152-9

2. Jack K.C. Ng., Li P.K.-T. Chronic kidney disease epidemic: How do we deal with it? Nephrology, vol. 23, no. 4, pp. 116-120. DOI: 10.1111/nep.13464

3. Hill N.R., Fatoba S.T., Oke J.L., Hirst J.A., O'Callaghan C.A., Lasserson D.S., Richard Hobbs F.D. Global prevalence of chronic kidney disease - A systematic review and Meta-analysis. PLoS One, 2016, vol. 6, no. 11 (7), pp. e0158765. DOI: 10.1371/journal.pone.0158765

4. Gansevoort R.T., Correa-Rotter R., Hemmelgarn B.R., Jafar T.H., Heerspink H.J., Mann J.F., Matsushita K., Wen C.P. Chronic kidney disease and cardiovascular risk: epidemiology, mechanisms, and prevention. Lancet, 2013, vol. 382, no. 9889, pp. 339-352. DOI: 10.1016/s0140-6736(13)60595-4

5. Go A.S., Chertow G.M., Fan D., McCulloch C.E., Hsu C.Y. Chronic kidney disease and the risks of death, cardiovascular events, and hospitalization. The New Engl. J. Med., 2004, vol. 351, no. 13, pp. 1296-1305. DOI: 10.1056/NEJMoa041031

6. Etgen T., Chonchol M., Forstl H., Sander D. Chronic Kidney Disease and Cognitive Impairment: A Systematic Review and Meta-Analysis. American journal of nephrology, 2012, vol. 35, no. 5, pp. 474-482. DOI: 10.1159/000338135

7. Perlman R.L., Finkelstein F.O., Liu L., Roys E., Kiser M., Eisele G., Burrows-Hudson S., Messana J.M. [et al.]. Quality of life in chronic kidney disease (CKD): a cross-sectional analysis in the Renal Research Institute-CKD study. Am. J. Kidney. Dis., 2005, vol. 45, no. 4, pp. 658-666. DOI: $10.1053 /$ j.ajkd.2004.12.021

8. Chin H.J., Song Y.R., Lee J.J., Lee S.B., Kim K.W., Na K.Y., Kim S., Chae D.-W. Moderately decreased renal function negatively affects the health-related quality of life among the elderly Korean population: a population-based study. Nephrol. Dial. Transplant, 2008, vol. 23, no. 9, pp. 2810-2817. DOI: $10.1093 / \mathrm{ndt} / \mathrm{gfn} 132$

9. Global, Regional, and National Age-Sex-Specific Mortality for 282 Causes of Death in 195 Countries and Territories, 1980-2017: A Systematic Analysis for the Global Burden of Disease Study 2017. Lancet, 2018, vol. 392, no. 10159, pp. 1736-1788. DOI: 10.1016/S0140-6736(18)32203-7

10. Plantinga L.C., Johansen K., Crews D.C., Shahinian V.B., Robinson B.M., Saran R., Burrows N.R., Williams D.E. [et al.]. Association of CKD with disability in the United States. Am. J. Kidney. Dis., 2011, vol. 57, no. 2, pp. 212-227. DOI: 10.1053/j.ajkd.2010.08.016

11. GBD 2016 DALYs and HALE Collaborators. Global, regional, and national disabilityadjusted life-years (DALYs) for 333 diseases and injuries and healthy life expectancy (HALE) for 195 countries and territories, 1990-2016: A systematic analysis for the Global Burden of Disease Study 2016. Lancet, 2017, vol. 392, no. 10159, pp. 1859-1922. DOI: 10.1016/S0140-6736(18)32335-3

12. Eriksson J.K., Neovius M., Jacobson S.H., Elinder C.G., Hylander B. Healthcare costs in chronic kidney disease and renal replacement therapy: A population-based cohort study in Sweden. BMJ Open, 2016, vol. 7, no. 6, pp. e012062. DOI: 10.1136/bmjopen-2016-012062 
13. Chronic Kidney Disease: Evaluation, Classification, and Stratification 2002. KDOQI. NewYork, National Kidney Foundation Publ., 2002, 356 p.

14. CG73 Chronic kidney disease: full guideline 2008. The published full clinical guideline on Chronic kidney disease including recommendations and methods used. NICE NIfCE. Available at: http://guidance.nice.org.uk/CG73/Guidance/pdf/English (06.09.2019).

15. De Lusignan S., Tomson C., Harris K., Van Vlymen J., Gallagher H. UK Prevalence of Chronic Kidney Disease for the Adult Population Is $6.76 \%$ Based on Two Creatinine Readings. Nephron Clinical practice, 2012, vol. 120, pp. 107. DOI: 10.1159/000337124

16. Coresh J., Selvin E., Stevens L.A., Manzi J., Kusek J.W., Eggers P., Van Lente F., Levey A.S. Prevalence of chronic kidney disease in the United States. JAMA, 2007, vol. 298, no. 17, pp. 2038-2047. DOI: 10.1001/jama.298.17.2038

17. Coresh J., Byrd-Holt D., Astor B.C., Briggs J.P., Eggers P.W., Lacher D.A., Hostetter T.H. Chronic kidney disease awareness, prevalence, and trends among U.S. adults, 1999 to 2000. J. Am. Soc. Nephrol., 2005, vol. 16, no. 1, pp. 180-188. DOI: 10.1681/ASN.2004070539

18. Coresh J., Astor B.C., Greene T., Eknoyan G., Levey A.S. Prevalence of chronic kidney disease and decreased kidney function in the adult US population: Third National Health and Nutrition Examination Survey. American Journal of Kidney Diseases, 2003, vol. 41, no. 1, pp. 1-12. DOI: $10.1053 /$ ajkd.2003.50007

19. Aitken G.R., Roderick P.J., Fraser S., Mindell J.S., O'Donoghue D., Day J., Moon G. Change in prevalence of chronic kidney disease in England over time: comparison of nationally representative cross-sectional surveys from 2003 to 2010. BMJ open, 2014, vol. 4, no. 9, pp. e005480. DOI: 10.1136/bmjopen-2014-005480

20. Saran R., Robinson B., Abbott K.C., Agodoa L.Y.C., Albertus P., Ayanian J., Balkrishnan R., Bragg-Gresham J. [et al.]. US Renal Data System 2016 Annual Data Report: Epidemiology of kidney disease in the United States. Am. J. Kidney Dis., 2017, vol. 69, no. 3(1), pp. A7-A8. DOI: 10.1053/j.ajkd.2016.12.004

21. Gilg J., Methven S., Casula A., Castledine C. UK renal registry 19th annual report: Chapter 1 UK RRT adult incidence in 2015: National and Centre-specific analyses. Nephron, 2017, vol. 137, no. 1, pp. 11-44. DOI: 10.1159/000481363

22. Liu Z.H. Nephrology in China. Nat. Rev. Nephrol, 2013, vol. 9, no. 9, pp. 523-538. DOI: 10.1038/nrneph.2013.146

23. Mills K.T., Xu Y., Zhang W., Bundy J.D., Chen C.-S., Kelly T.N., Chen J., He J. A systematic analysis of world-wide population-based data on the global burden of chronic kidney disease in 2010. Kidney Int, 2015, vol. 88, no. 5, pp. 950-957. DOI: 10.1038/ki.2015.230

24. Bowe B., Xie Y., Li T., Mokdad A.H. Changes in the US burden of chronic kidney disease from 2002 to 2016: an analysis of the global burden of disease study. JAMA Netw Open, 2018, vol. 2, no. 1 (7), pp. e184412. DOI: 10.1001/jamanetworkopen.2018.4412

25. Imtiaz S., Salman B., Qureshi R., Drohlia M.F., Ahmad A. A review of the epidemiology of chronic kidney disease in Pakistan: A global and regional perspective. Saudi J Kidney Dis Transpl, 2018, vol. 29, no.6, pp. 1441-1451. DOI: 10.4103/1319-2442.248307

26. Gerasimova O.Yu., Semchenko L.N., Remenets S.S. Epidemiologiya khronicheskikh boleznei pochek i organizatsiya meditsinskoi pomoshchi bol'nym pri khronicheskoi pochechnoi nedostatochnosti (obzor literatury) [Epidemiology of chronic kidney diseases and organization of medical aid provided for patients with chronic kidney failure (literature review)]. Yuzhno-ural'skii meditsinskii zhurnal, 2016, no.4, pp. 4-9 (in Russian).

27. Bikbov B.T., Tomilina N.A. Zamestitel'naya terapiya terminal'noi khronicheskoi pochechnoi nedostatochnosti v Rossiiskoi Federatsii v 1998-2013 gg. Otchet po dannym Rossiiskogo registra zamestitel'noi pochechnoi terapii. Chast' pervaya [Substitute therapy for treating terminal kidney failure in the Russian Federation in 1998-2013. A report issued basing on data provided by the Russian register of substitute kidney therapy. Part I.]. Nefrologiya i dializ, 2015, no. 3, 111 p. (in Russian). 
28. Apolikhin O.I., Kakorina E.P., Sivkov A.V. Official statistics on urological morbidity in the Russian Federation. Urologiya, 2008, no. 3, pp. 3-9 (in Russian).

29. Jessani S., Bux R., Jafar T.H. Prevalence, determinants, and management of chronic kidney disease in Karachi, Pakistan - a community based cross-sectional study. BMC Nephrol, 2014, vol. 13, no. 15, pp. 90. DOI: 10.1186/1471-2369-15-90

30. Kalantar-Zadeh K., Golan E., Shohat T., Streja E., Norris K.C., Kopple J.D. Survival disparities within American and Israeli dialysis populations: learning from similarities and distinctions across race and ethnicity. Semin Dial, 2010, vol. 23, no. 6, pp. 586-594. DOI: 10.1111/j.1525139X.2010.00795.x

31. Newsome B.B., Kilpatrick R.D., Liu J., Zaun D., Solid C.A., Nieman K., St Peter W.L. Racial differences in clinical use of cinacalcet in a large population of hemodialysis patients. Am. J. Nephrol., 2013, vol. 38, no. 2, pp. 104-114. DOI: 10.1159/000353298

31. Koh H.K., Piotrowski J.J., Kumanyika S., Fielding J.E. Healthy People a 2020 vision for the social determinants approach. Health Education \& Behavior, 2011, vol. 38, no. 6, pp. 551-557. DOI: $10.1177 / 1090198111428646$

33. Laster M., Shen J.I., Norris K.C. Kidney disease Among African Americans: A population perspective. Am J. Kidney Dis.,_2018, vol. 72, no. 5 (1), pp. S3-S7. DOI: 10.1053/j.ajkd.2018.06.021

34. Saran R., Robinson B., Abbott K.C., Agodoa L.Y.C., Bhave N., Bragg-Gresham J., Balkrishnan R., Dietrich X. [et al.]. US Renal Data System 2017 Annual Data Report: epidemiology of kidney disease in the United States. Am. J. Kidney Dis., 2018, vol. 71, no. 3 (1), pp. S1-S672. DOI: 10.1053/j.ajkd.2018.01.002

35. Gao S.W., Oliver D.K., Das N., Hurst F.P., Lentine K.L., Agodoa L.Y., Sawyers E.S., Abbott K.C. Assesment of Racial Disparities in chronic kidney disease stage 3 and 4 care in the department of defense health system. Clin. J. Am. Soc. Nephrol., 2008, vol. 3, no. 2, pp. 442-449. DOI: $10.2215 / C J N .03940907$

36. Mathur R., Dreyer G., Yaqoob M.M., Hull S.A._Ethnic differences in the progression of chronic kidney disease and risk of death in a UK diabetic population: an observational cohort study. BMJ Open, 2018, vol. 27, no. 8 (3), pp. e020145. DOI: 10.1136/bmjopen-2017-020145

37. Taylor D.M., Fraser S., Dudley C., Oniscu G.C., Tomson C., Ravanan R., Roderick P. Health literacy and patient outcomes in chronic kidney disease: a systematic review. Nephrology Dialysis Transplantation, 2018, vol. 33, no. 9, pp. 1545-1558. DOI: 10.1093/ndt/gfx293

38. Fraser S.D.S., Roderick P.J., Casey M., Taal M.W., Yuen H.M., Nutbeam D. Prevalence and associations of limited health literacy in chronic kidney disease: a systematic review. Nephrology Dialysis Transplantation, 2013, vol. 28, no. 1, pp. 129-137. DOI: 10.1093/ndt/gfs371

39. Koople J.D. National Kidney Foundation. K/DOQI clinical practice guidelines for chronic kidney disease: evaluation, classification, and stratification. Am. J. Kidney Dis., 2001, vol. 37, no. 1 (2), pp. S66-S70. DOI: 10.1053/ajkd.2001.20748

40. Verhave J.C., Troyanov S., Mongeau F., Fradette L., Bouchard J., Awadalla P., Madore F. Prevalence, awareness, and management of CKD and cardiovascular risk factors in publicly funded health care. Clin. J. Am. Soc. Nephrol., 2014, vol. 9, no. 4, pp. 713-719. DOI: 10.2215/CJN.06550613

41. Ene-Iordache B., Perico N., Bikbov B., Carminati S., Remuzzi A., Perna A., Islam N., Flores Bravo R. [et al.]. Chronic kidney disease and cardiovascular risk in six regions of the world (ISN-KDDC): A cross-sectional study. Lancet Glob. Health, 2016, vol. 4, no. 5, pp. e307-e319. DOI: $10.1016 / \mathrm{S} 2214-109 \mathrm{X}(16) 00071-1$

42. Chow K.M., Szeto C.C., Kwan B., Leung C.B., Li P.K. Public lacks knowledge on chronic kidney disease: Telephone survey. Hong Kong Med. J., 2014, vol. 20, no. 2, pp. 139-144. DOI: 10.12809/hkmj134134

43. Jafar T.H., Ramakrishnan C., John O., Tewari A., Cobb B., Legido-Quigley H., Sungwon Y., Jha V. Access to CKD Care in Rural Communities of India: a qualitative study exploring the barriers and potential facilitators. BMC Nephrol, 2020, no. 21, pp. 26. DOI: 10.1186/s12882-020-1702-6 
44. Choukem S.-P., Nchifor P.K., Halle M.-P., Nebongo D.N., Mboue-Djieka Y., Kaze F.F., Monekosso G.L. Knowledge of physicians on chronic kidney disease and their attitudes towards referral, in two cities of Cameroon: a cross-sectional study. BMC Res. Notes, 2016, no. 9, pp. 29. DOI: $10.1186 / \mathrm{s} 13104-016-1845-5$

45. Global Burden of Disease Study 2013 Collaborators. Global, regional, and national incidence, prevalence, and years lived with disability for 301 acute and chronic diseases and injuries in 188 countries, 1990-2013: a systematic analysis for the Global Burden of Disease Study 2013. Lancet, 2015, vol. 386, no. 9995, pp. 743-800. DOI: 10.1016/S0140-6736(15)60692-4

Aringazina A.M., Narmanova O.Zh., Nuskabaeva G.O., Tagaeva Zh.A., Mendybaev E.S. Chronic kidney disease: prevalence and risk factors (literature review). Health Risk Analysis, 2020, no. 2, pp. 164-174. DOI: 10.21668/health.risk/2020.2.18.eng

Received: 23.10.2019

Accepted: 13.06 .2020

Published: 30.06 .2020 